\title{
RESPONSIVITAS PELAYANAN UNIT GAWAT DARURAT DI PUSKESMAS JABIREN
}

\author{
Responsiveness of Emergency Unit Services at Jabiren Health Center
}

\section{Hamberi* $^{*}$ \\ Dwi Rohmiatun}

Universitas Muhammadiyah Palangkaraya, Palangka Raya, Central Kalimantan, Indonesia email: hamberi@umpalangkaraya.ac.id

\section{Kata Kunci:}

Responsivitas

Pelayanan

UGD

\section{Keywords:}

Responsiveness

Service

ER

Accepted

June 2017

Published

October 2017

\begin{abstract}
Abstrak
Penelitian ini bertujuan untuk mengkaji dan menjelaskan Responsivitas Pelayanan Unit Gawat Darurat (UGD) di Puskesmas Jabiren Kabupaten Pulang Pisau. Metode penelitian yang digunakan adalah deskriptif kualitatif karena masalah yang dibawa oleh peneliti masih belum jelas bersifat sementara dan bersifat holistic (menyeluruh) sumber data dalam penelitian ini terdiri dari data primer dan sekunder yang menjadi data primer adalah kepala Puskesmas Jabiren, bidan, perawat/petugas-petugas medis, dan masyarakat yang menerima fasilitas pelayanan UGD di Puskesmas Jabiren. Teknik pengumpulan data dalam penelitian ini yaitu observasi, wawancara dan dokumentasi. Berdasarkan hasil penelitian bahwa Responsivitas Pelayanan UGD di Puskesmas Jabiren diketahui masih belum maksimal karena perawat/ bidan seringkali tidak tepat waktu dalam memberikan pelayanan di UGD, pernah terjadi kesalahan saat proses pelayanan kesehatan, obat-obatan yang masih kurang, sumber daya manusia masih kurang, dan masih kurang sarana fasilitas penunjang pelayanan di UGD.
\end{abstract}

\begin{abstract}
This study aims to examine and explain the Responsiveness of Emergency Unit Services (UGD) at Jabiren Health Center, Pulang Pisau Regency. The research method used is descriptive qualitative because the problems brought by researchers are still unclear in nature and are holistic (overall) sources of data in this study consisting of primary and secondary data which is the primary data is the head of Jabiren Health Center, midwife, nurse / officer-medical staff, and the community who received ED services at the Jabiren Health Center. Data collection techniques in this study are observation, interview, and documentation. Based on the results of the survey that the responsiveness of emergency services in Jabiren Health Center is known to be still not optimal because nurses/midwives often do not deliver on time in the ED services, there have been mistakes during the health care process, medicines are still lacking, human resources are still lacking, and there are still facilities for supporting facilities at the ER.
\end{abstract}

\section{PENDAHULUAN}

Pelayanan kebutuhan dasar yang harus diberikan pemerintah meliputi kesehatan, pendidikan dasar, dan bahan kebutuhan pokok masyarakat. Kesehatan merupakan salah satu kebutuhan dasar masyarakat, maka kesehatan adalah hak bagi setiap warga masyarakat yang dilindungi oleh Undang- undang dasar.

Sesuai dengan undang-undang diatas menjelaskan bahwa masyarakat mendapatkan jaminan dari pemerintah bahwa mereka akan selalu dapat memelihara dan meningkatkan kesehatan yang dibutuhkan. Namun hingga saat ini banyaknya kritik dan tuntutan masyarakat terhadap kualitas pelayanan, karena masih menunjukkan masyarakat yang belum merasa puas dengan kinerja birokrasi terutama dalam memberikan pelayanan di unit gawat darurat. Keluhan pasien baik tentang lamanya waktu pelayanan dan adanya ketidakpuasan pelanggan, serta sarana/fasilitas ini bisa menjadi salah satu tanda kurangnya responsivitas pihak Unit Gawat Darurat (UGD) diPuskesmas Jabiren dalam menangani permasalahan kesehatan pasien, kebutuhanan dan keluhan pasien.

Responsivitas rendah ditunjukkan karena adanya ketidakselarasan antara pelayanan yang ada dan kebutuhan masyarakat. Hal ini bisa menunjukkan gagalan suatu organisasi dalam mewujudkan tujuan dan misi puskesmas. Dengan demikian apabila pihak puskesmas 
jabiren dapat dikatakan bertanggungjawab jika mereka dinilai memiliki responsivitas yang tinggi terhadap apa yang menjadi permasalahan, dan keluhan pasien.

Masalah yang terjadi dalam pelayanan kesehatan, maka sangat penting responsivitas pelayanan di Unit Gawat Daruat (UGD) di puskesmas agar pelayanan yang diberikan itu sesuai dengan apa yang diharapkan masyarakat sebagai pasien sehingga pelayanan yang baik dapat diwujudkan. Pusat Kesehatan Masyarakat (Puskesmas) adalah salah satu sarana pelayanan kesehatan masyarakat yang sangat penting, tujuan dari pelayanan untuk tercapainya derajat masyarakat Jabiren yang memuaskan harapan dan kebutuhan derajat masyarakat. Puskesmas Jabiren merupakan puskesmas induk yang ada di Kecamatan Jabiren Raya, di Puskesmas Jabiren sudah dilengkapi dengan fasilitas pelayanan Unit Gawat Darurat (UGD) yang mana pelayanannya 24 jam untuk melayani masyarakat. Unit Gawat Darurat (UGD ) salah satu bagian pelayanan di puskesmas yang menyediakan penanganan awal bagi pasien yang menderita sakit dan cedera yang mengancam kelangsungan hidup, pertolongan pertama pasien yang mengalami kondisi gawat darurat pada saat berada dipuskesmas secara cepat, tepat dan bersifat sementara. Hal ini karena puskesmas adalah ujung tombak unit pelayanan pertama untuk masyarakat yang membutuhkan petolongan.

Menurut Sampara (Hardiyansyah 20II) mengemukakan bahwa kualitas pelayanan adalah pelayanan yang diberikan kepada pelanggan sesuai dengan standar pelayanan yang telah dibakukan sebagai pedoman dalam memberikan layanan. Standar pelayanan adalah ukuran yang telah ditentukan sebagai suatu pembakuan pelayanan yang baik. Begitu juga menurut Tangkilisan (2005) Reponsivitas adalah kemampuan birokrasi untuk mengenali kebutuhan masyarakat, menyusun agenda dan prioritas pelayanan, serta mengembangkan programprogram pelayanan sesuai dengan kebutuhan dan aspirasi masyarakat. Secara singkat responsivitas disini menunjuk pada keselarasan antara program dan kegiatan pelayanan dengan kebutuhan dan aspirasi masyarakat.

Dalam bahasa Inggris kata "health" mempunyai pengertian dalam bahasa Indonesia, yaitu "sehat" atau “kesehatan”. Sehat menjelaskan kondisi atau keadaan dari subjek, misalnya anak sehat, orang sehat, ibu sehat, dan sebagainya. Sedangkan kesehatan menjelaskan tentang sifat dari subjek, misalnya kesehatan manusia, kesehatan binatang, kesehatan masyarakat, kesehatan individu, dan sebagainya (Notoatmodjo, 2010). Menurut Winslow (Setiowati, 2016) kesehatan masyarakat adalah ilmu dan seni, dalam mencegah penyakit, memperpanjang hidup, dan meningkatkan kesehatan melalui usaha-usaha pengorganisasian masyarakat untuk:

I. Perbaikan sanitasi lingkungan

2. Pemberantasan penyakit menular

3. Pendidikan untuk kebersihan perorangan

4. Pengorganisasian pelayanan-pelayanan medis dan perawatan untuk diagnosis dini dan pengobatan.

Dalam Peraturan Menteri Kesehatan Republik Indonesia Nomor 19 Tahun 2016 Tentang Sistem Penanggulangan Gawat Darurat Terpadu Pasal I Gawat Darurat adalah keadaan klinis pasien pasien yang membutuhkan tindakan medis segera untuk penyelamatan nyawa dan pencegahan kecacatan. Pelayanan gawat darurat tindakan medis yang dibutuhkan oleh korban/pasien gawat darurat dalam waktu segera untuk menyelamatkan nyawa dan pencegahan kecacatan.

\section{METODOLOGI}

Metode yang digunakan dalam penelitian ini metode kualitatif. Penelitian kualitatif adalah penelitian dimana peneliti ditempatkan sebagai instrument kunci, teknik pengumpulan data dilakukan secara penggabungan dan analisis data bersifat induktif. Metode kualitatif digunakan untuk mendapatkan data yang mendalam, 
suatu data yang mengandung makna. Makna adalah data sebenarnya, data yang pasti merupakan suatu nilai dibalik data yang tampak.

\section{HASIL DAN PEMBAHASAN}

Responsivitas atau ketanggapan merupakan kemauan dalam membantu dan memberikan pelayanan yang cepat, tepat, cermat, dan waktu yang tepat kepada pengguna layanan, dengan menyampaikan informasi yang berkaitan dengan keperluan pelayanan yang jelas. Pelayanan yang responsif atau tanggap juga sangat dipengaruhi oleh cara sikap atau sifat pegawai dalam melayani. Salah satunya adalah kesigapan dan ketulusan dalam memberikan pelayanan kepada masyarakat sebagai pengguna layanan.

Pelayanan unit gawat darurat di Puskesmas Jabiren dalam merespon setiap pelanggan/pasien masih kurang baik tidak sesuai dengan harapan masyarakat antara lain sikap petugas yang masih belum ramah terhadap pasien yang datang ke unit gawat darurat, tidak melayani masyarakat dikarenakan tidak sesuai dengan tugas pokoknya, sedangkan pasien yang datang membutuhkan pelayanan dari petugas pelayanan.

Pelayanan dengan cepat masih belum maksimal dikarenakan sumber daya yang dimiliki unit gawat darurat masih kurang terlihat ketika petugaspetugas sering merangkap kepekerjaan lain, dan kewalahan ketika masyarakat yang datang banyak, sehingga kurangnya tenaga kesehatan akan memperlambat suatu pelayanan, petugas kesehatan sudah cepat tanggap ketika ada pasien yang datang, walaupun ada beberapa petugas yang masih kelihatan acuh apabila masyarakat, sarana dan prasarana yang menunjang pelayanan masih minim di unit gawat darurat, hal itu yang sering membuat pelayanan kurang baik, seperti obat-obatan yang masih minim, kursi ruang tunggu hanya ada beberapa jika pasien sepuluh hingga lima belas orang maka pasien sering berdiri karena tidak ada lagi kursi untuk menunggu, dan ketika panas, ruang tunggunya kena sinar matahari, membuat suasana pasien yang menunggu kurang enak. Keberadaan sarana dan prasarana dalam menyediakan fasilitas pokok maupun penunjang dalam proses pelayanan merupakan dasar bagi masyarakat dalam merasakan pelayanan. Apabila sarana dan prasarana tidak optimal dalam penyelengaraan pelayanan maka hal tersebut menyebabkan ketidaknyaman bagi pengguna layanan ketika melakukan proses pelayanan. Sehingga tidak tercapai pelayanan yang baik dengan kebutuhan dan harapan masyarakat.

Pelayanan pendaftaran di unit gawat darurat hanya dilakukan dengan cara menulis dibuku, hanya dilakukan siapa yang datang duluan itulah yang dilayani terlebih dahulu. Pelayanan yang diberikan petugas sering tidak tepat, terdapat kekeliruan dalam melayani, dan terlihat petugas terburu-buru menangani pasien. Dan tidak jarang petugas melakukan kesalahan dalam pelayanan, dikarena petugas kurang konsentrasi saat melayani pasien yang berobat. Hal seperti ini membuat pelayanan kesehatan tidak baik, berdampak negatif, dan merugikan setiap pasien. Jika terjadi kesalahan-kesalahan yang fatal maka akan mengganggu keselamatan pasien yang berobat.

Kecermatan dalam merawat maupun pembicaraan dalam penyampaian informasi terhadap masyarakat/pasien merupakan salah satu faktor yang berdampak besar terhadap kesembuhan pasien.Kecermatan petugas unit gawat darurat ini dilakukan dengan selalu memberikan pelayanan yang terbaik kepada pasiennya.

Kegiatan pelayanan kesehatan diunit gawat darurat merupakan kegiatan yang berhadapan langsung dengan pasien yang membutuhkan pelayanan, maka dari itu petugas kesehatan harus mampu untuk memberikan penjelasan informasi dengan baik dan mudah untuk dipahami, komunikasi yang baik antar petugas dan pasien, sehingga pasien yang berobat tidak merasa canggung untuk menceritakan apapun keluhannya. 
Petugas harus memberikan pelayanan dengan keahlian dan pengetahuannya, unit gawat darurat harus mewujudkan tenaga kesehatan yang profesional serta berkualitas yaitu dengan cara memalui peningkatan kompetensi keahlian, pelatihan, study banding, serta pelatihan untuk tenaga kesehatannya, karena pelayanan kesehatan langsung kontak dengan kesehatan manusia.

Dalam hal ini kompetensi petugas harus ditetapkan dengan tepat berdasarkan pengetahuan, keahlian, keterampilan, sikap dan perilaku yang dibutuhkan. Waktu merupakan elemen penting dalam menjamin kepuasan pengguna pelayanan. Ketepatan waktu penyelesaian pelayanan sebagai jaminan selesainya setiap pelayanan. Masyarakat pengguna pelayanan mengharapkan waktu pelayanan benar-benar tepat.Pelayanan dengan waktu yang tepat masih belum bisa diterapkan oleh petugas unit gawat darurat, seringkali petugas datang ke unit gawat darurat tidak tepat waktu karena berbagai alasan. Seharusnya petugas kesehatan yang datang terlebih dulu ke unit gawat darurat, namun yang terlihat pasien yang lebih dulu datang dan menunggu petugas unit gawat daruratnya. $\mathrm{Hal}$ itu membuat petugas kesehatan bekerja seringkali tidak tepat waktu dalam melayani. Waktu yang diperlukan untuk pelayanan dari tahap awal hingga akhir hanya memerlukan waktu dua puluh menit sampai dua puluh menit, tergantung dari petugas yang menangani dan jumlah pasien yang datang berobat. Respon petugas untuk setiap keluhan-keluhan sudah baik, namun penanganan setiap pengaduan dari pasien masih belum dievaluasi, terlihat dari kotak saran masih tidak ada diunit gawat darurat, kotak saran tersebut berfungsi untuk mendapatkan informasi maupun masukan terkait dengan pelayanan diunit gawat darurat.

\section{KESIMPULAN}

Dalam memberikan pelayanan di unit gawat darurat petugas kesehatan masih bersikap tidak baik, terlihat dari keluhan setiap pasien yang datang bahwa petugas cenderung bersikap dan berkomunikasi tidak sopan ketika menangani pasien yang gawat, dan kasar dalam melayani. Kecepatan memberikan pelayanan di Puskesmas Jabiren khususnya di Unit Gawat Darurat masih kurang cepat tanggap, dikarenakan tenaga kesehatan yang ada belum memadai, serta jadwal piket untuk petugas unit gawat darurat belum ditetapkan secara tertulis, sehingga pelayanan di UGD pun menjadi lambat, sedangkan pasien yang berada di UGD harus segera diberikan pertolongan.

Dari segi sarana dan prasarana yang menunjang untuk kecepatan sebuah pelayanan masih minim di Unit Gawat Darurat seperti kasur, gorden pembatas, alat-alat medis, obat-obatan masih kurang mencukupi, dan kebersihan di Unit Gawat Darurat masih tidak bersih, hal ini membuat pelayanan yang ada menjadi kurang maksimal dan masih jauh untuk bisa dikatakan pelayanan prima. Mengenai ketepatan waktu proses pelayanan di Unit Gawat Darurat yang diberikan oleh petugas kesehatan tidak maksimal, tidak akurat, karena tim medis seringkali tidak tepat waktu dalam memberikan pelayanan seperti datang terlambat, diruangan Unit Gawat Darurat sering tidak ada satupun petugas kesehatan, sehingga masyarakat yang membutuhkan pertolongan harus menunggu sampai petugasnya ada ditempat. Pelayanan yang diberikan dari tahap awal hingga selesai untuk pasien memerlukan waktu sekitar dua puluh menit dan tergantung dari banyaknya jumlah pasien yang datang. Dalam hal ini ketepatan waktu petugas baik itu dokter, perawat, maupun bidan serta petugas lainnya dalam memberikan pelayanan dan penanganan harus lebih diperhatikan lagi agar pelayanan yang diharapkan masyarakat menjadi lebih baik dan berkualitas lagi.

\section{REFERENSI}

Azwar, Azrul. 2010. Pengantar Administrasi Kesehatan. Tangerang: Bina Rupa Aksara. 
Basuki, Johanes. 20I3. Budaya Pelayanan Publik. Jakarta: Harmoko Media Pustaka.

Dwiyanto, Agus. 2005. Mewujudkan Good Governance Melalui Pelayanan Publik. Yogyakarta: Gadjah Mada University Press.

Dwiyanto, Agus. 2006. Reformasi Birokrasi Publik di Indonesia. Yogyakarta: Gadjah Mada University Press.

Emzir. 2012. Metodogi Penelitian Kualitatif : Analisis Data. Jakarta: Raja Grafindo Persada.

Gunawan, Imam. 2014. Metode Penelitian Kualitatif Teori dan Praktek. Jakarta: Bumi Aksara

Handayani, I.T. 20I5. Kualitas Pelayanan Pada Pasien Eawat Inap Di Rumah Sakit Islam PKU Muhammadiyah Palangkaraya. Pencerah Publik. 2(I):43-48.

Hardiyansyah. 20II. Kualitas Pelayanan Publik. Yogyakarta: Gava Media.

Hutasoit .20ll. Pelayanan Publik Teori dan Aplikasi. Jakarta: Magnascript Publishing.

Moelong, J Lexy. 2012. Metode Penelitian Kualitatif. Bandung: Remaja Rosdakarya.

Moenir, HAS. 200I. Manajemen Pelayanan Umum di Indonesia. Jakarta: Bumi Aksara.

Nasution. 2004. Manajemen Mutu Terpadu (Total Quality Manajement). Jakarta: Ghalia Indonesia

Nasution. 2005. Manajemen pelayanan Terpadu Edisi Kedua. Jakarta: Ghalia Indonesia

Pasolong, Harbani. 20II. Teori Administrasi Negara. Bandung: Alfabeta.

Peraturan Menteri Kesehatan Republik Indonesia Nomor 19 Tahun 2016 Tentang Sistem Penanggulangan Gawat Darurat Terpadu

Peraturan Menteri Kesehatan Republik Indonesia Nomor 75 Tahun 2014 Tentang Pusat Kesehatan Masyarakat Undang-Undang Republik Indonesia Nomor 36 Tahun 2009 Tentang Kesehatan.

Ratminto dan Winarsih Septi Atik, 2005. Manajemen Pelayanan : Pengembangan Model Konseptual, Penerapan Citizen's Charter dan Standar Pelayanan Minimal. Yogyakarta: Pustaka Pelajar.
Sedarmayanti. 2004. Good Governance. Bandung: Mandar Maju.

Tangkilisan, S.N Hessel. 2005. Manajemen Publik. Jakarta: Genesindo. 